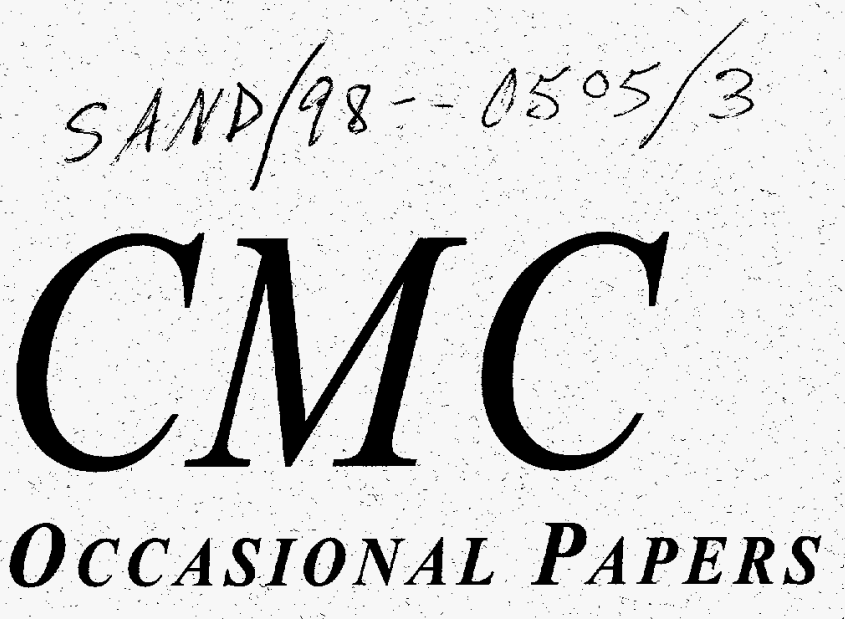

SECEIVEO APR 2 C 989

OSTI

\title{
Movements of People, Ideas, Trade and Technology: Toward a Peaceful Coexistence of India and Pakistan
}

\author{
Samina Ahmed \\ Consultant, The Asia Foundation, \\ Islamabad, Pakistan \\ Suranjan Das \\ Professor, University of Calcutta, \\ Calcutta, India
}


Issued by Sandia National Laboratories, operated for the United States Department of Energy by Sandia Corporation.

NOTICE: This report was prepared as an account of work sponsored by an agency of the United States Government. Neither the United States Government nor any agency thereof, nor any of their employees, nor any of their contractors, subcontractors, or their employees, makes any warranty, express or implied, or assumes any legal liability or responsibility for the accuracy, completeness, or usefulness of any information, apparatus, product, or process disclosed, or represents that its use would not infringe privately owned rights. Reference herein to any specific commercial product, process, or service by trade name, trademark, manufacturer, or otherwise, does not necessarily constitute or imply its endorsement, recommendation, or favoring by the United States Government, any agency thereof, or any of their contractors or subcontractors. The views and opinions expressed herein do not necessarily state or reflect those of the United States Government, any agency thereof, or any of their contractors.

Printed in the United States of America. This report has been reproduced directly from the best available copy.

Available to DOE and DOE contractors from

Office of Scientific and Technical Information

PO Box 62

Oak Ridge, TN 37831

Prices available from (615) 576-8401, FTS 626-8401

Available to the public from

National Technical Information Service

US Department of Commerce

5285 Port Royal Rd.

Springfield, VA 22161

NTIS price codes

Printed Copy: A03

Microfiche Copy: A01 


\title{
Movements of People, Ideas, Trade, and Technology: Toward a Peaceful Coexistence of India and Pakistan
}

Samina Ahmed

Consultant, The Asia Foundation, Islamabad, Pakistan

\author{
Suranjan Das \\ Professor, University of Calcutta, \\ Calcutta, India
}

Cooperative Monitoring Center Occasional Paper $/ 3$

\subsection{Sandia National Laboratories}

Sandia is a multiprogram laboratory operated by Sandia Corporation, a Lockheed Martin Company, for the United States Department of Energy under contract DE-AC04-94AL85000.
DISTRIBUTION OF THIS DOCUMENT IS UNLLMTED<smiles>CCCCC=C(C)C</smiles> 
The Cooperative Monitoring Center (CMC) at Sandia National Laboratories assists political and technical experts from around the world to acquire the technology-based tools they need to assess, design, analyze and implement nonproliferation, arms control and other cooperative security measures. As part of its mission, the CMC sponsors research on cooperative security and the role of technology. Reports of that work are provided through the Occasional Papers series. Research is conducted by Sandia staff as well as visiting scholars. The CMC visiting scholars program is administered by the Institute for Public Policy at the University of New Mexico. For additional information on the programs of the $\mathrm{CMC}$, visit the $\mathrm{CMC}$ home page on the World Wide Web at $<$ http://www.cmc.sandia.gov> or write to:

Cooperative Monitoring Center

Sandia National Laboratories

Mail Stop 1373

Albuquerque, NM 87185-1373

For specific information on this report contact:

Kent L. Biringer at the above address.

This report was prepared by Sandia National Laboratories

Albuquerque, NM 87185 and Livermore, CA 94550 


\section{DISCLAIMER}

Portions of this document may be illegible electronic image products. Images are produced from the best available original document. 


\title{
Movements of People, Ideas, Trade, and Technology: Toward a Peaceful Coexistence of India and Pakistan
}

\begin{abstract}
The potential exists for peaceful and constructive bilateral relations between India and Pakistan. Domestic developments in both countries, the changing global economic and political environment, and structural changes in regional trading patterns have created new opportunities for replacing traditional Indian and Pakistani perceptions of hostility and suspicion with mutual understanding and trust. This substitution process can be accelerated by increasing people-to-people contact, the free flow of information, and economic and technological cooperation between the two neighbors.

Nonmilitary confidence building measures could create conditions for an incremental reduction on tensions between India and Pakistan. A popular consciousness for enhanced bilateral cooperation is growing. This process could be strengthened by identifying and exploring new areas of mutually beneficial cooperation that could pave the way for peace.
\end{abstract}


Movements of People, Ideas, Trade, and Technology:

This page intentionally left blank. 


\section{Contents}

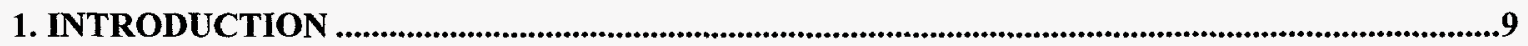

2. MOVEMENTS OF PEOPLE ….......................................................................................................11

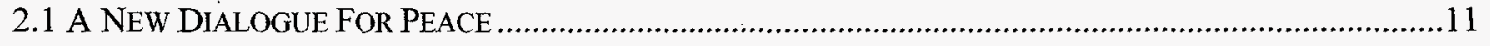

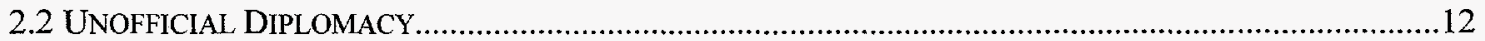

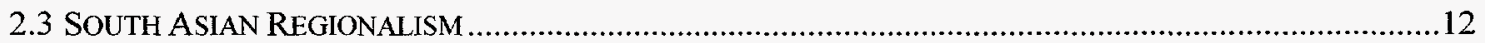

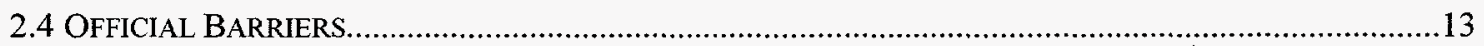

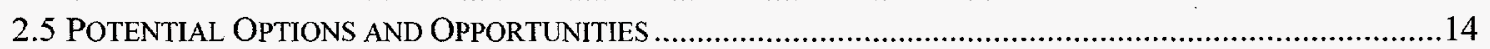

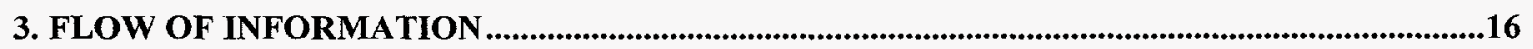

3.1 THE CURRENT STATE OF THE FLOW OF IDEAS AND INFORMATION ..................................................16

3.2 UNOFFICIAL DIALOGUE, REGIONAL INITIATIVES, AND CROSS-BORDER COMMUNICATION ...................17

3.3 TECHNOLOGICAL DEVELOPMENTS AND PROSPECTS FOR THE FUTURE ……......................................18

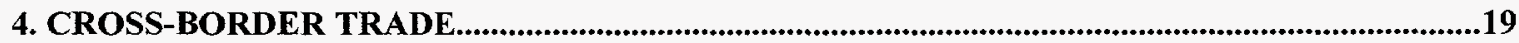

4.1 Bilateral CoOPERATION N TRADE AND COMMERCE: A Plausible SCENARIO..................................20

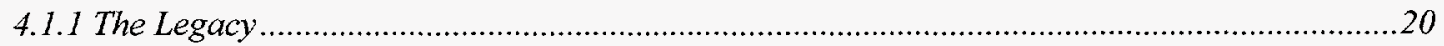

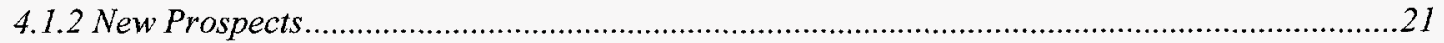

5. COOPERATIVE TECHNOLOGICAL RELATIONSHIP BETWEEN INDIA AND PAKISTAN:

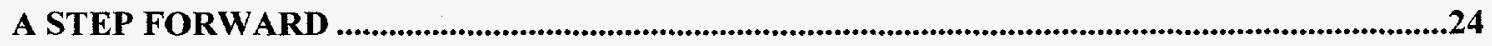

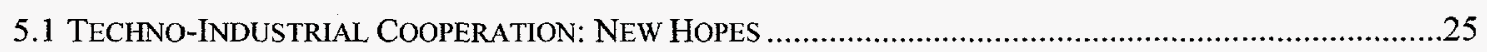

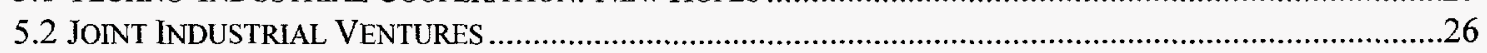

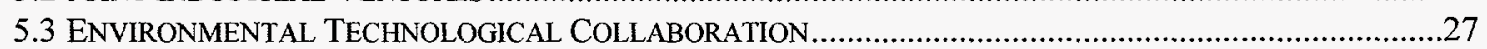

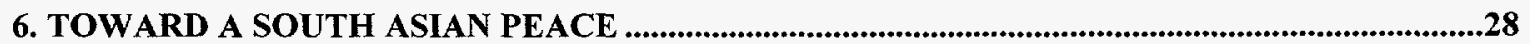

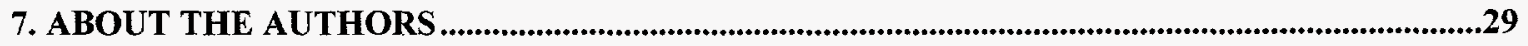




\section{Acronyms}

CBM confidence building measures

$\mathrm{CMC}$ Cooperative Monitoring Center

FICCI Federation of Indian Chamber of Commerce and Industries

FISME Federation of Indian Micro Small and Medium Enterprises

FPCCI Federation of Pakistan Chamber of Commerce and Industry

FPCTC Federation of Pakistan Chambers of Traders and Cottage Industries

MFN

$\mathrm{MOU}$ Most Favored Nation

RCSS Memorandum of Understanding

SAARC Regional Center for Strategic Studies

SAFTA South Asian Association for Regional Cooperation SAPTA South Asian Free Trade Area South Asian Preferential Trading Arrangement 


\section{Movements of People, Ideas, Trade, and Technology:}

\section{Toward a Peaceful Coexistence of India and Pakistan}

\section{Introduction}

As recently as 1997, a peace dialogue has been launched by the political leaderships of India and Pakistan, creating new opportunities to restructure relations along peaceful lines, breaking the diplomatic stalemate of the past decade. Complex political and security issues will have to be resolved before the two countries can fully normalize their relations. A step-by-step approach can, however, be adopted to initiate confidence building measures in nonmilitary areas, with the objective of establishing a more cooperative relationship that will help to reduce tensions, creating, in turn, a favorable atmosphere for more substantive negotiations on contentious issues such as Kashmir. ${ }^{1}$

An essential component of this process will be the replacement of traditional perceptions of hostility and suspicion with mutual understanding and trust. This process can be accelerated by increasing people-to-people contact, the free flow of information, and economic and technological cooperation between the two countries. This paper assesses and identifies options for expanding such bilateral interaction and examines political and technological mechanisms that could be used to contain and counter hindrances to such bilateral interaction.

After a three-year period of noncommunication, India and Pakistan reopened their diplomatic dialogue to discuss their bilateral differences as their foreign secretaries met in New Delhi in April 1997. The dialogue continued when the Indian Prime Minister Inder K. Gujral and his Pakistani counterpart Mian Nawaz Sharif held their first formal meeting in May 1997 at the summit of the South Asian Association for Regional Cooperation (SAARC) in New Delhi. Since the May summit, several meetings have been held between the Indian and Pakistani leaderships and higher bureaucracies. Although there has been no major breakthrough in the relationship, the continuation of the dialogue indicates commitment on the part of both countries to find avenues of resolving or, at the very least, containing bilateral tensions and exploring opportunities for cooperation.

This new climate of peace results from domestic developments in both countries including democratic governance and the liberalization of previously controlled and centralized economies. The post-Cold War international environment is equally favorable

\footnotetext{
1 Endorsing incremental improvement of India-Pakistan relations in areas such as the movement of people, visas, trade, and communication at a news conference in New Delhi, UN Secretary-General Kofi Annan stressed, "we should go ahead and resolve those issues we can to build goodwill, and in time resolve all the issues. You do not refuse to move ahead because you cannot resolve the most difficult issue. ." The News, April 8, 1997.
} 
because all major extra-regional actors, including the United States, Russia, and China, support a peaceful resolution of Indo-Pakistani differences. ${ }^{2}$ New opportunities have emerged as a result of this changed atmosphere. This document:

- $\quad$ examines the possibilities for restructuring governmental policies that have previously acted as constraints on increased cooperation between India and Pakistan, and thereby permit a freer exchange of peoples across national frontiers.

- $\quad$ analyzes bilateral and unilateral concerns, including the flow of illegal immigrants.

- $\quad$ identifies cooperative monitoring mechanisms that could assuage official fears that have restricted the movements of people.

- $\quad$ assesses the present state of information flows, including the media policies of the two countries.

- $\quad$ examines the significance of new information technology for the dissemination of ideas.

The promotion of bilateral economic and technological cooperation will lay the foundation for an enduring peace, because increased economic interdependence will necessitate the normalization of political relations. Changed international, regional, and internal dynamics have created new opportunities for enhancing economic and technical collaboration. In the post-Cold War world, reduced Western financial assistance and the existence of economic regional groupings in Europe, Asia, and North America are forcing India and Pakistan to rely increasingly on bilateral and regional economic and technological linkages for sustaining their economic growth. Evidence of progress toward this goal includes the positive response to the creation of a South Asian free-trade area and the incremental expansion of bilateral economic interaction. Prospects for technological cooperation have also increased as a result of new opportunities arising from changed unilateral and bilateral dynamics as well as the availability of new technologies.

At the same time, however, concerns must be addressed to sustain the momentum of such cooperation and to fully exploit new options and opportunities. Thus, existing infrastructural and policy-related impediments will have to be removed and alternative avenues explored. Nonmilitary confidence building measures such as increased peopleto-people contact, the free flow of information, and enhanced economic and technological collaboration will reduce bilateral tensions and promote détente.

\footnotetext{
${ }^{2}$ Dr. Maleeha Lodhi, "Talk about Talks," The News, April 5, 1997; K.K. Katyal, "Hopes of a Thaw in Indo-Pakistan Ties," The Hindu, February 4, 1997.
} 


\section{Movements of People}

Recent diplomatic initiatives by the governments of New Delhi and Islamabad have generated new hopes for a peaceful resolution of Indo-Pakistani differences. Confidence building measures should also help to create additional constituencies with an inherent stake in peace. As a first step, both governments could negotiate ways of expanding people-to-people contacts.

Any progress toward peace requires reducing mutual suspicions and hostility at the official level and within segments of civil society. While dialogue among policy makers (including parliamentarians and bureaucrats) is vital, an informed public is equally essential to change the Cold War mind-set in both countries. Greater interaction between Indian and Pakistani opinion makers and other individuals, groups, and organizations in civil society is an essential requirement for developing an informed public opinion.

Fear of a domestic backlash through the manipulation of public opinion by internal opponents has always posed major challenges for the Indian and Pakistani political leaderships whenever past attempts have been undertaken to restructure their bilateral relationship. ${ }^{3}$ Mutual ignorance and prejudices are the product of decades of separation caused by state policies that discouraged cross-border movement. People-to-people contacts can provide Indian and Pakistani officials with informal avenues for exploring new ideas and initiatives without fear of domestic repercussions.

\subsection{A New Dialogue For Peace}

The series of high-level and high-profile meetings held between the Indian and Pakistani leaderships and bureaucracies has begun to prepare the ground for a change in public perceptions. Pakistan's Prime Minister Nawaz Sharif and India's Prime Minister I.K. Gujral held high profile meetings at the May 1997 Male summit, at the United Nations General Assembly session in September 1997, and at the Commonwealth Heads of State and Government summit in Edinburgh in October 1997. In public statements at domestic and international forums, the Indian and Pakistani prime ministers repeatedly emphasized the need to normalize relations. Although India's United Front government was dissolved in December 1997 and elections are due in February 1998, any future Indian government is unlikely to abandon the peace dialogue that serves the national interests of both states.

There is also an ongoing dialogue between the higher bureaucracies of India and Pakistan. Given the task of identifying potential opportunities for promoting mutual cooperation and removing present constraints in bilateral relations, foreign secretary-level meetings, for example, are examining ways of enhancing people-to-people contacts, acknowledging the importance of mutual interaction.

\footnotetext{
3 Zafar Abbas, "Breaking the Ice," The Herald, March 1997, pp. 32-33.
} 


\subsection{Unofficial Diplomacy}

People-to-people contacts through track-two and track-three diplomacy have also begun to prepare the Pakistani and Indian public for an end to the long-standing diplomatic impasse. Several track-two and track-three dialogues have been underway since the early 1990 s. $^{4}$

Defined as "a process of unofficial dialogues between disputing polities conducted directly or with the help of a third party, by influential citizens who normally have access to their governments and/or an ability to influence public opinion," is carried on at informal forums by unofficial actors with access to policy-making circles. These informal channels of communication are aimed at identifying alternative policy options that would help to break the India-Pakistan diplomatic impasse. ${ }^{6}$ Many of the track-two dialogues have been sponsored by the United States, which is motivated by the desire to contain tensions and to prevent conflict between the two nuclear-capable states.

Track-three diplomacy has been initiated by individuals and groups within civil society in India and Pakistan, "aiming to build constituencies for peace which can question conventional practices and beliefs and present alternatives to official government positions." The objectives of track-three diplomacy are to promote mutual understanding through people-to-people contacts, to diffuse existing and latent tensions by creating an informed public opinion, and to use public pressure on governments to restructure their bilateral relations.

\subsection{South Asian Regionalism}

The South Asian Association for Regional Cooperation (SAARC), a seven-member body formed in 1985, provides another channel of official and unofficial communication between the Indian and Pakistani governments and peoples. Although the SAARC Charter excludes politically contentious issues from the organization's agenda, quiet diplomacy, such as bilateral meetings between the Indian and Pakistani prime ministers, has successfully defused some tensions. SAARC has placed special significance on expanding people-to-people interaction. This includes the roles played by SAARC's affiliated associations, including the Association of SAARC Speakers and

\footnotetext{
${ }^{4}$ Inventory of South Asian unofficial dialogues in Navnita Chadha Behera, Paul M. Evans and Gowher Rizvi, Beyond Boundaries: A Report on the State of Non-Official Dialogues on Peace, Security and Cooperation in South Asia (Joint Center for Asia Pacific Studies, University of Toronto, Toronto, 1997), pp. 62-98.
}

${ }^{5}$ Sundeep Waslekar, Track-Two Diplomacy in South Asia (ACDIS Occasional Paper, Program in Arms Control, Disarmament and International Security, University of Illinois at Urbana-Champaign, Champaign, Second Edition, 1995), p. 1.

\footnotetext{
${ }^{6}$ Sandeep Waslekar, op.cit., p. 5.

${ }^{7}$ Navnita Chada Behera, Paul M. Evans, Gowher Rizvi, op.cit., p. 19.
} 
Parliamentarians and SAARC Law, in advancing regional exchanges among influential segments of South Asian policy and opinion-making circles. SAARC has also instituted various regional mechanisms to promote people-to-people contacts, discussed in greater detail in this section.

Unofficial channels of communication have had mixed results in creating greater mutual trust. Several of the ongoing track-two and track-three dialogues exist only on paper. Moreover, many unofficial track-two dialogues are restricted to selected retired civil and military bureaucrats or co-opted academics and merely serve as channels for the reiteration of official perceptions and views. No real attempt is made to identify or suggest options that could reduce bilateral tensions. Nor do such dialogues foster a climate for peace among the Indian and Pakistani people, since the public is deliberately kept uninformed about the results of the dialogues. Some track-two activities, such as the USIA-sponsored traveling seminars, are more open to the public, and thus have greater internal credibility. They have, however, been limited to segments of the Indian and Pakistani opinion-making elite and have so far had little or no impact, beyond that of pressure on governments.

Track-three activities have helped to create links between segments of civil society in both states. There are, for example, regular exchanges of delegations by the IndiaPakistan People's Forum for Peace and Democracy, a key track-three actor. ${ }^{8}$ Although track-three activities have created legitimacy for and acceptance of the role of unofficial dialogue between the Indian and Pakistani people, governmental mistrust of these dialogues has limited their effectiveness in influencing policymakers.

\subsection{Official Barriers}

The effectiveness of people-to-people undertakings is severely undermined by officially imposed restrictions. Participants in track-two and track-three activities often face difficulties in obtaining visas. The visa regime in India and Pakistan is a major barrier. As a result, succeeding generations of Indians and Pakistanis have little or no first-hand knowledge of each other, which perpetuates images based on hostility and suspicion.

According to the India-Pakistan bilateral visa regime, visitors can enter only from fixed points. Despite long land borders, there are no road links. Only one biweekly train service, the Samjhauta Express, crosses the border at a single point, Wagah-Attari, via Amritsar in the Indian Punjab and Lahore, the capital of Pakistan's Punjab province. ${ }^{9}$

\footnotetext{
${ }^{8}$ The India-Pakistan People's Forum, composed of a cross-section of Indian and Pakistani society including journalists, lawyers, politicians, trade unionists, and social activists, has so far held annual conventions in Lahore, New Delhi, and Calcutta. The Calcutta Declaration of the Forum, issued in December 1996, calls for bilateral agreements on free travel across the India-Pakistan border and reduction of communication and travel costs and free exchange of information and publications. The Island, January 24, 1997.

${ }^{9}$ Pakistani passengers are taken straight to New Delhi and are not allowed to disembark en route.
} 
Entry by air or by sea is restricted to a limited number of entry points and the same entry and exit points must be used. ${ }^{10}$ Travel within India and Pakistan is restricted to a limited number of cities, and permission for specific cities must be acquired in advance. Cumbersome police reporting procedures for Indian and Pakistani visitors do little to promote goodwill between visitor and host.

In 1997, India made unilateral travel concessions, including (1) visas for Pakistani tourist groups, (2) one-year multiple entry visas for businessmen, who would be allowed to exit either though Mumbai or Delhi, (3) exemption from police reporting for senior Pakistani citizens, and (4) a waiver of visa fees for some categories of visitors, including journalists and students. ${ }^{11}$ These concessions are still too limited to affect the majority of Pakistani visitors. Pakistan has not reciprocated this symbolic gesture.

Under the aegis of SAARC, visa exemptions for categories of South Asian citizens include the senior judiciary, parliamentarians, the heads of national academic institutions, and heads of chambers of commerce and industry. Although the SAARC exemption scheme is limited to the political and economic elite, attempts are underway to increase these categories.

Both states strongly resist unrestricted movement of Indian and Pakistani citizens across their respective national borders and within their national territories. Even participants in officially approved track-two dialogues find their activities hampered by bureaucratic delays in obtaining visas as well as by internal travel restrictions and by hindrances such as police reporting. In both countries, bureaucratic resistance to free movement and access is often justified by claims that unrestricted movement may threaten national security by encouraging terrorist infiltration or espionage. ${ }^{12}$ Other justifications include the desire to curb the influx of illegal economic migrants, ${ }^{13}$ and the necessity to counter smuggling and the cross-border traffic in arms and narcotics.

\subsection{Potential Options and Opportunities}

Continuing the present peace dialogue could help to address national security concerns regarding hostile activities such as terrorism or espionage. Until the two countries allow free travel across their borders, some incremental measures could be taken to ease visa restrictions and to provide greater travel options. As a first step, reopening the Indian

${ }^{10}$ Entry points by air are restricted to Karachi, Lahore, and Islamabad in Pakistan and Mumbai, New Delhi, and Amritsar in India. Entry by sea is through the ports of Karachi (Pakistan) and Mumbai (India).

${ }^{11}$ Announcing these concessions, Foreign Minister I.K. Gujral declared that this "major unilateral step" was taken in "keeping with (the) Indian policy to promote people-to-people relations." The Hindustan Times, March 21, 1997; Dawn, March 21, 1997.

${ }^{12}$ See, for example, views expressed by a former Indian official. Maloy Khrishna Dhar, "The "Third Track' to Pakistan," Indian Express, April 2, 1997.

${ }^{13}$ In a statement before Parliament, the Pakistani Interior Minister, Chaudhry Shujaat Hussain claimed that there were 100,000 illegal Indian immigrants in Karachi alone. Dawn, September 5, 1997. 
consulate general in Karachi and the Pakistani consulate general in Mumbai, shut down during a period of increased tensions in 1994, would build confidence. The reopening of the consulates would also (1) reduce pressure on the Indian and Pakistani embassies in New Delhi and Islamabad, thus expediting visa applications, and (2) lessen travel time for citizens who apply for visas. Reopening the consulates would be particularly useful for the business community, since both Mumbai and Karachi are major centers of finance and commerce.

Other incremental measures ${ }^{14}$ to relax the visa regime include:

- Relaxing or eventually eliminating cumbersome police reporting procedures

- Gradually increasing the number of cities specified in the visa to allow freer movement within national territories, followed by a removal of the ban

- Identifying new ports of entry, including air and rail links

Additional air or rail routes could be efficiently monitored either unilaterally or, if political conditions permit, through collaborative means. ${ }^{15}$

India and Pakistan could also cooperatively monitor the cross-border movement of illegal immigrants and create joint mechanisms to deal with traffic in smuggled goods, arms, and narcotics. During the dialogue initiated by Prime Ministers Rajiv Gandhi and Benazir Bhutto, an agreement was signed in 1989 for bi-annual meetings between the DirectorGeneral of the Pakistan Rangers and the Inspector General of the Indian Border Security Force on issues such as cross-border smuggling, illegal border crossings, and drug trafficking. ${ }^{16}$ According to one source, meetings held between Pakistani and Indian Interior and Defense Secretaries had suggested "joint patrolling" or "parallel patrolling" as one way to check illegal movement across the border. No attempt was made to give concrete shape to these suggestions because the dialogue broke down in $1994 .{ }^{17}$

Since the resumption of the dialogue, these suggestions can be revived. Extensive cooperative monitoring of their long common border is not economically feasible nor politically desirable, because enhanced military presence in border areas increases

\footnotetext{
${ }^{14}$ Many of these measures were suggested in the statement issued in Dhaka in June 1996 by the group of eminent citizens of India and Pakisitan monitoring the Bangladesh parliamentary poll as members of the SAARC observers' team. "Dhaka Statement of Citizens of India and Pakistan," Mainstream, July 6, 1996, p. 19.

${ }^{15}$ At present, Indian and Pakistani customs and immigration officials are responsible for clearing the passengers. The crossing on both sides of the border, where a barbed wire fence has been erected, is also policed by paramilitary forces.

${ }^{16}$ Sumit Ganguly, "Mending Fences," Michael Krepon and Amit Sevak, eds., Crisis Prevention, Confidence Building, and Reconcilation in South Asia (A Henry L. Stimson Center Book, St, Martin's Press, New York, 1995), p. 13.

${ }^{17}$ K.K. Katyal, "A Diary of Indo-Pakistan Talks," The Nation, April 5, 1997.
} 
tensions. However, Indian and Pakistani security agencies could identify and jointly monitor major access routes to curb activities such as smuggling and the traffic in narcotics and arms. Similarly, joint patrolling of demarcated sea lanes could remove a long-standing source of tension between the two countries.

Indian and Pakistani fishermen frequently intrude, often inadvertently, into the territorial waters of the other country because they are unable to discern demarcation lines. As a result, scores of fishermen are arrested and their craft impounded by the security agencies of both countries. ${ }^{18}$ In 1997, as a gesture of goodwill, the Sharif government released 38 underage Indian fishermen held in captivity for over three years. ${ }^{19}$ Soon after, however, intruding fishermen and their craft were once again seized by both sides. Should India and Pakistan agree to cooperatively police jointly defined and demarcated coordinates, they could also curb smuggling, thereby institutionalizing a confidence building measure that would also benefit their national economies. ${ }^{20}$

\section{Flow of Information}

Relaxing the curbs on cross-border movement is also essential for another important and relatively neglected dimension of the ongoing peace process, the flow of ideas across national frontiers. Exchange of information and ideas could play an important role in replacing traditional perceptions of hostility and suspicion by mutual understanding. At present, not only is transborder movement restricted, but both states also discourage communication and the flow of ideas between the Indian and Pakistani peoples.

\subsection{The Current State of the Flow of Ideas and Information}

As a result of conscious government policies, media flows between the two countries have been minimal. There is no exchange of newspapers, magazines, and other media instruments. Difficulties in obtaining visas, internal restrictions on movement, and the interference of state agencies combine to prevent members of the independent print media from performing their duties. ${ }^{21}$ Because the electronic media is state-controlled in both India and Pakistan, it serves the primary purpose of projecting official propaganda and

\footnotetext{
18 By Pakistani accounts, Indian coastal guards had detained 34 Pakistani boats and 233 crewmen from 1993 to January 1997. Asian Age, March 22, 1997. For an Indian perspective see R.K. Misra, "Pakistanis are Fishing in Troubled Indian Waters," Pioneer, December 22, 1996.

${ }^{19}$ The Asian Age, March 22, 1997.

20 At the moment, there is no agreement between the two states on the exact coordinates determining the limits of their territorial waters, continguous zones, exclusive economic zones, and the continental shelf. Asian Age, November 28, 1996.

21 The number of journalists posted in the other country is decided by the Indian and Pakistani governments and their internal movement is restricted by the city-specific visa policy.
} 
perpetuating official and often hostile perceptions. ${ }^{22}$ The flow of information and ideas across national barriers is also minimal at the academic level because there are no direct exchanges, either in the form of personnel or publications between universities, thinktanks, and other institutions of learning. Very little information is available in each country about the other. This mutual state of ignorance is further reinforced by illinformed academic texts, research publications, and print media analyses that shape elite as well as mass opinion. ${ }^{23}$

As a consequence of these official impediments, centers of learning and the print media are unable to prepare public opinion and to contribute to policy-making when the two governments decide to change the directions of their bilateral relationship from hostility to peace. Recognizing the need to address this problem, some steps have been taken to facilitate bilateral access to information. The Gujral government, for example, permitted the import of Pakistani books and periodicals, a measure which has yet to be reciprocated by Pakistan. ${ }^{24}$

\subsection{Unofficial Dialogue, Regional Initiatives, and Cross-border Communication}

Some track-two activities have attempted to bridge the information gap between the independent Pakistani and Indian press media. Senior Indian and Pakistani journalists participate in the USIA-sponsored traveling seminars. To avoid publishing inflammatory or false information and to promote media availability in both countries, these journalists have:

- held meetings in Indian and Pakistani cities, including Karachi, Islamabad, Lahore, Mumbai and New Delhi in 1997; and,

- decided to work together to maximize accurate reporting.

Their objective is to create deeper understanding for building better relations. ${ }^{25}$ Visa and travel restrictions hinder these goals.

While there is very little academic interaction between India and Pakistan, some progress has been made through SAARC channels and South Asian regional institutes such as the Regional Center for Strategic Studies (RCSS). The RCSS sponsors regional workshops and collaborative research projects. SAARC has established chairs, fellowships, and

\footnotetext{
${ }^{22}$ According to a Pakistani journalist, both the Indian and the Pakistani governments fight a "proxy war" through their state-controlled electronic media. Anjum Niaz, "The Road Not Taken: Pakistani Journalist's Perception of Indo-Pak Relations," Mainstream, November 18, 1995, p. 7.

${ }^{23}$ Sumit Ganguly, op.cit., pp. 19-20.

24 The Hindu, March 21, 1997.

${ }^{25}$ Agreement has also been reached to establish a Pakistan-India Press Council. The Nation, March 20, 1997.
} 
scholarships in Indian and Pakistani academic institutions. SAARC visa exemptions have been granted to the heads of South Asian academic institutions and academies; and there are suggestions to further expand academic categories in the SAARC visa exemption scheme. $^{26}$

Despite their willingness to support such measures in the SAARC forum, Indian and Pakistani policy-makers selectively apply SAARC policies and bilateral initiatives. For example, Indian and Pakistani state-controlled education bureaucracies have largely ignored the December 1988 cultural agreement reached between Prime Ministers Bhutto and Gandhi on the rewriting of history books to remove deliberate distortions and the perpetuation of enemy images.

\subsection{Technological Developments and Prospects for the Future}

Policies of economic liberalization and new information and communications technologies have begun to shrink the information gap, overcoming bureaucratic resistance. For the past several decades, Indian and Pakistani audiences have relied on foreign radio channels for information, revealing a lack of trust in the state-controlled broadcast media. In the wake of economic liberalization, the state no longer exercises a monopoly over television networks and privately-owned networks have been established.

Avenues of information have been further diversified because of foreign satellite television networks. Satellite television channels have also brought Indian and Pakistani television programs to viewers in both countries. Although official restrictions hamper the print media, mainstream Indian and Pakistani newspapers are now available on the Internet. ${ }^{27}$ The Internet has also opened new channels of information and communication between Indians and Pakistanis, providing an alternative to slow and undependable postal routes, and inadequate and unreliable land telecommunication links.

The significance of changed state media policies or the impact of new information and communications technologies on the flow of ideas and information between India and Pakistan must not, however, be over-estimated. Private managers of radio and television networks, for the most part, take care to project state perceptions and views on sensitive areas such as defense and foreign policy. Much of the new technology is subject to state control and is accessible only to the Indian and Pakistani elite. Thus far, satellite television has had little relevance to a majority of the population, which has, at best, access to state-controlled television channels. Access to computer hardware and most information technology is beyond the reach of most Indians and Pakistanis.

\footnotetext{
${ }^{26}$ At the conference of SAARC tourism ministers in Colombo in October 1997, a proposal was made to allow journalists visa-free travel within the SAARC region, while the Association of SAARC Speakers and Parliamentarians, at their second conference in Islamabad in October 1997, recommended that visa restrictions be eased to promote free movement in the region. The conference also recommended a South Asia student dialogue and the exchange of data through e-mail and the Internet. Dawn, October 22, 1997; October 29, 1997.

27 C. Raja Mohan, "Breaching the Indo-Pak Barrier: Try the Internet," The Hindu, August 26, 1996.
} 
Communication via the information highway is monitored by state agencies, discouraging an open dialogue between Indian and Pakistani users.

While an open exchange of ideas about military security issues on the Internet is likely to remain the subject of official suspicion and vulnerable to official retribution, web sites could be devoted to noncontroversial subjects such as health, education, and the environment. The Association of SAARC Speakers and Parliamentarians has specifically recommended the creation of a SAARC parliamentary website on the Internet, so that regional parliamentarians are informed of developments within all regional states. ${ }^{28}$ Because economic ties will be central to sustained reconciliation between India and Pakistan, information technologies can be used for exchanging ideas and data to assist official and unofficial sectors in expanding cross-border trade.

\section{Cross-Border Trade}

South Asia is a site of multiple contradictions. It represents 3 percent of the world's area, but houses 21 percent of the global population. The region which is a repository of rich-mostly untapped - natural resources, has the potential to be the largest global industrial market, and has a common cultural legacy. Yet, it remains plagued by poverty, unemployment, and inadequate economic growth and social progress.

Resolution of developmental contradictions in India and Pakistan requires structural change, in their political economies. But some short-term measures could be undertaken for a balanced developmental process in the two countries. A mere 5 percent reduction in the annual military budget of the two countries would release about US $\$ 2$ billion which could help fulfill basic social needs of the people in the region. ${ }^{29}$ But this cannot be envisioned without a change in the relationship between India and Pakistan. A series of military confidence building measures (CBMs), already attempted between the two neighbors, has fallen far short of the desired results. ${ }^{30}$

The changing dynamics of the international political economy and regional politics in the post-Cold War period have offered new opportunities and challenges for India-Pakistan economic and technical collaboration. First, the demise of the Soviet Union and the end of the Cold War has freed South Asia from external alliances that had divided India and Pakistan. Second, current official Western financial assistance is directed mostly to the successor states of the former Soviet bloc. The per capita international aid for South Asia is presently only US $\$ 5$. Third, while a recent World Bank report, "South Asia's Integration into the Global Economy," predicts the region will have "the world's fastest

28 Dawn, October 29, 1997.

29 Jayashree Sengupta, "South Asia Should Leap Frog to Catch Up with East Asia," Business and Political Observer, May 5, 1997; Mahbub-ul-Haq, Human Development in South Asia (Oxford University Press, Oxford, 1997).

30 Samina Yasmeen and Aabha Dixit, Confidence-building Measures in South Asia (The Henry Stimson Center Occasional Paper No. 24 September 1995). 
growth in exports" by 2028 , the rate of economic growth in major industrialized states is likely to be relatively slower. ${ }^{31}$ This implies that India and Pakistan cannot count on their traditional Western markets for their expanding economies. Fourth, regional economic groupings like the North American Free Trade Agreement, the European Union, the ASEAN Free Trade Area, the Central American Common Market, Latin American Free Trade Area, the Central African Customs and Economic Union, the East African Community, the Arab Common Market, the New Zealand-Australia Free Trade Area, and Common Market of the Southern Cone will impede the expansion of Indian and Pakistani commerce in those regions. Fifth, the end of the Soviet Union has shrunk India's export trade to Eastern Europe by 10 percent, making New Delhi look to South Asia for compensation. Sixth, Pakistan's traditional allies (the United States, China, and Iran) are pushing Islamabad toward rapprochement with New Delhi. Finally, the recent structural adjustment programs in both countries can only be sustained by economic competition and not counterproductive military rivalries between the two neighbors.

Internal developments have created new domestic pressures in favor of cooperative bilateral relations between India and Pakistan. In both countries, there is growing awareness among an expanding middle class, intellectuals, and a young generation, untouched directly by the trauma of partition, that cooperation is worth pursuing rather than fighting wars. In addition, an expanding Indian middle class-the size being roughly equivalent to the total U.S. population-is more interested in economic links with Pakistan than sustaining military and political tensions. The existence of this potential market has attracted the interest of Pakistani businessmen. Thus, business lobbies in both countries have developed as pressure groups in favor of economic cooperation between India and Pakistan.

\subsection{Bilateral Cooperation in Trade and Commerce: A Plausible Scenario}

\subsubsection{The Legacy}

India and Pakistan were parts of the same economic unit. In the aftermath of partition, more than 70 percent of Pakistan's trading transactions were with India; 63 percent of Indian exports were comprised of manufactured items, and 92 percent of Pakistani imports consisted of food and raw materials. ${ }^{32}$ Political compulsions, however, resulted in a decline of India-Pakistan official trade from Indian Rs. 1,850,000,000 in 1948-49 to an

\footnotetext{
${ }^{31}$ South Asia's Integration into the Global Economy (World Bank, Washington DC, 1997).

32 Rehman Sobhan, "Regional Economic Cooperation in South Asia: Legacy and Prospects," Economic Bulletin for Asia and Pacific, XXX, I, June 1979. See also Gowher Rizvi, South Asia in a Changing International Order (Sage, New Delhi, 1993).
} 
all-time low of Indian Rs. 110,000,000 in 1965-66, which coincided with the second India-Pakistan war. ${ }^{33}$

The gradual severance of bilateral trading relations forced both Pakistan and India to adopt economic blueprints that undermined their self-sufficiency. Pakistan imported coal, steel, iron and even wheat from the West, China, and South Korea when it could have secured these commodities from India at half the price. India also incurred a considerable opportunity cost. For instance, areas more suitable for paddy cultivation were converted to jute cropping when Pakistan prohibited the export of raw jute to India. New Delhi imported pig iron and iron scrap from outside the region, although it could have been purchased from Pakistan at lower transportation costs.

\subsubsection{New Prospects}

The changing structure of the international political economy in the post-Cold War era and South Asian political and economic reform have opened up new prospects for IndiaPakistan commerce. Following an exchange of trade delegations, Pakistan agreed in July 1989 to allow import of 322 Indian items. By 1992-93, the value of India-Pakistan trade had more than tripled, rising to Indian Rs. 5,230,000,000 from Indian Rs. 1,690,000,000 in 1990-91..$^{34}$ The two sides also recognized the loss in state revenues from a thriving informal underground trade across the border, with an estimated volume of Indian Rs. 16 billion a year, four times more than the official bilateral trade. ${ }^{35}$ The size of this informal trade approaches Indian Rs. 20 billion per annum if supplies received by India and Pakistan through third countries are taken into consideration. Indian textile machinery, tannery equipment, chemical goods, cotton fabric, ayurvedic medicines, and cattle reach Pakistan through suppliers based in Dubai, Hong Kong, and Singapore. Pakistani goods entering India along unofficial routes include plastic goods, fiber fabrics, woolens, vegetable oil, etc. ${ }^{36}$

In 1996, Pakistan enthusiastically participated in the first SAARC industrial exhibition in Delhi. The Punjab-Harayana-Delhi Chambers of Commerce and the Federation of Pakistan Chambers of Commerce and Industries cooperated in preparing an inventory for expanding trade relations between India and Pakistan. ${ }^{37}$ The removal of hindrances to open trade could create opportunities for the use of idle or surplus capacities in Indian

\footnotetext{
33 Money figures in this paper have not been converted to U.S. dollars because the value of the Indian rupee has varied over time. These figures have been computed by I.N. Mukherji based on data from Director General of Commercial Intelligence, Government of India. I.N. Mukherji, "Indo-Pakistan Trade: Problems and Prospects," Himalayan and Central Asian Studies, Vol. 1, No. 1, April-June 1997.

34 News From The Indo-Pak Desk, Vol.X, December 1996 (PHD Chambers of Commerce and Industry, New Delhi, 1996). Also see Sabahat Alam, "Indo-Pak Trade Relations-From India with Hope," Pakistan and Gulf Economist, May 8-14, 1993; and Sunday Mail, May 16-22, 1993.

35 I.N. Mukherji, op.cit. Also see Dawn, February 9, 1997.

36 Ibid.

${ }^{37}$ News From The Indo-Pak Desk, op.cit. See Appendix - I.
} 
and Pakistani industries to meet the demands of a larger regional market. ${ }^{38}$ The two countries are also negotiating for the right to transit through each other's territories. While such an agreement would provide India an easy access to Central Asian markets, it would also expand Pakistan's trade with Bangladesh, Bhutan, and Nepal.

Structural changes in regional trading relations under the auspices of SAARC have also accelerated the pace of Indo-Pakistan trade. Intra-regional South Asian trade is still very low, comprising only 3.1 percent and 3.8 percent respectively of the total import and export trade of regional states at a time when 63.4 percent of Western Europe's global commerce consists of intra-European Union trade. The South Asian Preferential Trading Arrangement (SAPTA) - concluded in December 1995- has introduced integrative trading arrangements based on differential tariff concessions for 226 commodities. $^{39}$ In the second round of SAPTA, India offered concessions to Pakistan for 375 items and Pakistan reciprocated for 230 products. The SAARC Chambers of Commerce and Industry envision a South Asian Economic Union ${ }^{40}$ which, the U.S.-based Center for Trade Development estimates, would increase intra-SAARC trade five fold, from the present $\$ 3$ billion, to over $\$ 15$ billion by the year $2000 .^{41}$

Regrettably, the full potential for increased trade within the SAPTA-II framework still remains unrealized. For instance, in 1995-96 India imported from Pakistan only 17 out of the 375 products and exported only 37 of the 230 products that were granted preferential concessions. In Pakistan, the multinationals and their indigenous collaborators, selling over-priced consumer goods, have reportedly tried to sabotage the normalization of IndiaPakistan trade. ${ }^{42}$ There is also a perception that India has gained more from SAPTA-II than Pakistan. Among the products for which India received tariff concessions, for example, as many as 14 were already among the top fifty items exported to Pakistan. Islamabad, however, received concessions for only 5 of the items that comprised the top fifty products imported by India. ${ }^{43}$ Compared to Pakistan, moreover, India's trade policy is seen as less transparent, highly complex, and restrictive. ${ }^{44}$ Analysts now suggest that

\footnotetext{
${ }^{38}$ Aurangzeb A. Khan, "India and Pakistan: Confidence Building Through Free Trade and Joint Ventures" in Sony Devabhaktuni, ed., Regional Cooperation in South Asia: Prospects and Problems (The Henry L. Stimson Center, Occasional Paper No. 32, February 1997).

39 Rajesh Mehta and Swapan K. Bhattacharya, "SAPTA-I and SAPTA-II: Impact on India's Imports." Paper presented in a seminar on Economic Cooperation Among SAARC Countries: Challenges for Second Decade (Center For SAARC Studies, Andhra University, March 24-26, 1997).

${ }^{40}$ Sarkar Shah and Somen Mukerjee, "Vision, Goals and Strategies," Sarkar Shah and Somen Mukerjee, eds., Emerging South Asian Order (Media South Asia, Calcutta, 1997).

41 Ibid.

42 This is mostly seen in pharmaceuticals, tire industry, engineering sector, and automobile accessories. Kamal Siddiqi, "Between the Devil and the Deep Blue Sea," The Friday Times, April 3, 1997 ; Yusuf H. Shirazi, "Trade with India: Pros and Cons," The Sindh Tribune, March 4, 1997.

43 I.N. Mukherji, op.cit.

${ }^{44}$ See Report on the Tripartite Brainstorming Session on Tripartite Study for Expansion of Economic Cooperation in SAARC Region, ( Lahore, August 15, 1996).
} 
for SAPTA to be effective, it should be converted into an "across-the-board trade liberalization scheme." 45

Nevertheless, business groups in both countries are increasingly eager to tap a regional market, second in size only to China. Common tastes and culture should facilitate a regional market for goods produced in any part of the region. ${ }^{46}$ The feasibility of IndiaPakistan economic cooperation was demonstrated in the autumn of 1990 when India helped Pakistan withstand a potato and onion shortage, after Islamabad's effort to secure imports from extra-regional sources proved unsuccessful; and again in 1997 India helped Pakistan overcome a sugar shortfall. Many Indian businessmen are urging New Delhi to unilaterally initiate open trade with Pakistan. ${ }^{47}$ India has already accorded Pakistan Most Favored Nation status (MFN), while Islamabad has yet to grant MFN status to India. It should, however, be forthcoming, because of pressures from Pakistani society, especially from the business sector. The President of the Management Association of Pakistan, Tariq Ikram, reminded a 1996 seminar that since both India and Pakistan were signatories of the World Trade Organization, the question was no longer if the two states should trade with each other. Participating in the discussions, Tariq Sayeed Saigol, a leading manufacturer and exporter of textiles, believed that there was nothing to fear from trade with the Indian textile industry, provided his colleagues optimized cost of production and ensured quality production.

In March 1977, the National Shipping Corporation of Pakistan urged Islamabad to allow the country's shipowners to conduct third country trade with India. ${ }^{48}$ In April 1997, India and Pakistan agreed to expand official bilateral trade to more than 500 items. ${ }^{49}$ Pakistani commentators acknowledge that their country could particularly benefit by importing items like medicines from India where they are sold at less than 30 percent of the Pakistani prices, thanks to stricter control on multinationals. ${ }^{50}$

India, however, has to alleviate Pakistani fears that an opening of Pakistan's economy will not invite the hegemony of the Indian bourgeoisie. For instance, subsidies granted by the Indian government to the export sector reportedly put Pakistani products at a disadvantageous position. One way of gaining Pakistani confidence would be to adopt "a phased manner approach" in eliminating trade barriers. ${ }^{51}$ Tradable commodities could be

${ }^{45}$ Ibid.

${ }^{46}$ Jayashree Sengupta, "SAARC Should Get Down To Business," The Observer, August 12, 1996.

${ }^{47}$ See interview by Kantikumar Podar, the Mumbai-based business leader who is also Vice-President of SAARC Chambers of Commerce, The News, April 30, 1997.

48 The Nation, March 23, 1997.

49 The Nation, April 30, 1997.

${ }^{50}$ Pakistan and Gulf Economist, June 15-21, 1996.

${ }^{51}$ Mohammad Zubir Khan, "Trade with India: The Correct Decision," The News International, May 6, 1997. 
categorized into noncompeting, competing, and exempted products. ${ }^{52}$ While tariffs for the first category could be eliminated in the first phase of trade normalization, goods on which two countries compete should be brought within the preferential tariff system carefully and gradually. For mutually agreed upon exempted products, tariff barriers need not be immediately eliminated. This arrangement would provide a level playing field to the Pakistani business community. This is particularly important since the South Asian Preferential Trading Arrangement (SAPTA) is scheduled to be transformed to a South Asian Free Trade Area (SAFTA) in 2005. ${ }^{53}$

The new atmosphere in India-Pakistan trading relations is reflected in the signing of Memorandums of Understanding (MOUs) between the Federation of Indian Chamber of Commerce and Industries (FICCI) and the Federation of Pakistan Chamber of Commerce and Industry (FPCCI) on December 23, $1996^{54}$ and between the Federation of Indian Micro Small and Medium Enterprises (FISME) and Federation of Pakistan Chambers of Traders and Cottage Industries (FPCTC) in March $1997 .{ }^{55}$ While Indian businessmen have identified 207 export and 34 import items in their trade with Pakistan, their Pakistani counterparts have listed 153 export items and 152 import items for trade with India. Possible Indian exports to Pakistan could include agricultural and textile machinery, automobile parts, oil processing, telecommunications and engineering items, industrial chemicals, pharmaceutical materials, coal, and iron ore. Pakistani exports to India could consist of raw cotton, wool, blended fabrics, mineral substances, stainless steel, pesticides and insecticides, fertilizers, sports and surgical goods, plastic materials, and textiles.

\section{Cooperative Technological Relationship between India and Pakistan: A Step Forward}

Commercial connections between India and Pakistan could be sustained through the establishment of complementary technological relations. A SAARC Study Group on Economic Cooperation prescribed three-dimensional regional cooperation:

(1) collaborative efforts for technological upgrading to maintain global competition;

(2) improvement of technical capabilities where "global technological horizons" are

\footnotetext{
52 This was suggested by a Pakistani business delegation to India in December 1996. See Communalism Combat, No.29, January 1997. Also see Economic Cooperation in the SAARC Region: Potentials, Constraints and Politics (RIS, New Delhi, 1990); Shaping South Asia's Future: Role of Cooperation (Friedrich-Ebert Foundation Working Paper, Kathmandu, May 1994).

53 Indra Nath Mukherii, "Transition from SAPTA to SAFTA: Instruments and Modalities," Emerging South Asian Order, op.cit.

54 Economic Times, December 30, 1996; The News, December 24, 1996.

55 Dawn, March 22, 1997.
} 
rapidly changing; and (3) substitution of old technologies by more environmentally friendly applications. ${ }^{56}$

One way of using technology in building regional confidence and verifying agreements is through cooperative monitoring. This concept relies on using sharable technology and data to jointly monitor compliance with bilateral or regional security agreements. ${ }^{57}$ Cooperative monitoring applications have been employed internationally in many security contexts, including the implementation of conventional and nuclear arms control measures and for regional confidence building. They are designed to complement and not replace other national means of monitoring. By building confidence between nations, regional security can be enhanced while reducing the threat of conventional war and proliferation of weapons of mass destruction.

Cooperative monitoring measures also offer the potential for implementing nonmilitary agreements in areas such as border monitoring, pollution assessment, natural resource management, and monitoring of disasters such as earthquakes, storms, or oil spills. In the India-Pakistan context, cooperative monitoring has relevance for many areas: to counter undercover cross-border trade; to facilitate the removal of bottlenecks in ports of entry; and in preventing or responding to environmental disasters like oil spills.

\subsection{Techno-Industrial Cooperation: New Hopes}

Significant progress is yet to be attained in India-Pakistan technological collaboration. This has been partly due to traditional Pakistani rigidities. Pakistan Foreign Minister, Gohar Ayub Khan, for example, states: "We want India to resolve Kashmir and Siachen problems but it wants to discuss trade and other issues which are quite irrelevant at this stage. ${ }^{.58}$ Islamabad also fears that India, with its superiority in capital and intermediate technology, contributing 78 percent of the total manufacturing value in the region, would dump its products in Pakistan. ${ }^{59}$ But there are some positive signs on the political horizon. Pakistani Prime Minister Nawaz Sharif had agreed to resume talks with India without preconditions, remarking "we are 47 years late, we cannot afford any further delay." The outgoing Indian Prime Minister I.K. Gujral had likewise reiterated: "We don't want to be prisoners of the past and (are) trying to get rid of the mind set. ${ }^{~} 61$

\footnotetext{
56 Report on the Tripartite Brainstorming Session on Tripartite Study for Expansion of Economic Cooperation in SAARC Region, op.cit.

57 This concept has been developed by the Cooperative Monitoring Center at Sandia National Laboratories, Albuquerque, New Mexico, USA.

58 Pakistani Foreign Minister Gohar Ayub Khan's comment cited in Times of India, March 28, 1997.

${ }^{59}$ Rajive Kaul, "Industrial Cooperation in South Asia" in Emerging South Asian Order, op.cit.

${ }^{60}$ The News, February 14, 1997.

61 The Tribune, December 21, 1996.
} 
In the economic sphere, a South Asian Regional Convention on Intra-Regional Investment is likely to be agreed upon in the near future. ${ }^{62}$ An interim clearing and payments arrangement between India and Pakistan could end in a regional customs union. In this new political and economic climate, prospects for India-Pakistan technological collaboration have brightened.

A technical partnership would be beneficial to Pakistan since about 60 percent of its development budget relies upon foreign credit to import capital and intermediate goods. ${ }^{63}$ While the Indian Council of Scientific and Industrial Research could share with Pakistan its approximately 2000 industrial technologies, the Pakistan Council of Scientific and Industrial Research could transmit to India its improved techniques in food and fermentation technology, ore processing, metallurgy, glass and ceramics, paints and plastics, fine chemicals, polymers, industrial chemicals, and leather. Cooperation between the Pakistan and Indian Agricultural Research Councils could lead to improvement in pest control and seed breeding, making agriculture higher yielding and more cost effective.

Bilateral cooperation for technological upgrading in textiles, leather goods, jute manufactures, tea, rubber products, micro-electronics, biotechnology, and photovoltaics would be mutually beneficial for meeting global competition. In the $1980 \mathrm{~s}$, large deposits of rock phosphate were discovered at the Hazara region of Pakistan that could be processed economically with Indian technology. ${ }^{64}$ In paper production, India and Pakistan could collaborate to replace the wood-based technology with more environmentally friendly biogas-based techniques.

Telecommunication networks across the border can promote the flow of ideas, and a computer database-the SAARC Net-already promises closer interface between policy makers, commercial groups, and academics. ${ }^{65}$ The space program of the two countries, the INSAT and IRS for India and Badr-I and Badr-II for Pakistan, could also be coordinated. U.S.-Russia space programs have been fruitful, and space collaboration is planned between India and China.

\subsection{Joint Industrial Ventures}

Expert studies suggest that some joint India-Pakistan industrial ventures could leverage low-cost labor advantages to provide economical substitutes for expensive western

\footnotetext{
${ }^{62}$ Sarkar Shah and Somen Mukerjee, "Visions, Goals and Strategies," op.cit.; S.S. Colombage, "Payments and Monetary Cooperation in South Asia: Developments and Perspectives" in Perspectives on South Asian Cooperation (Coordinating Group For Studies On South Asian Perspectives, Islamabad, 1994).

${ }^{63}$ Gowher Rizvi, op.cit., pp. 159-60.

${ }^{64}$ Economic Cooperation In the SAARC Region: Potential, Constraints and Policies, op.cit., p. 185.

${ }^{65}$ Report of the Tripartite Brainstorming Session, op.cit.
} 
technologies. ${ }^{66}$ Coordination between multinational units operating in India and Pakistan, probably on the basis of division of labor, could hasten indigenous manufacturing capability and economies of scale. Such an experiment can be readily attempted for the existing Suzuki automobile and Yamaha motorcycle plants. ${ }^{67}$

Based on policy papers prepared by the two governments, as well as task forces constituted by the SAARC Secretariat, there could be technological collaboration in areas ranging from engineering goods to agricultural and food technology. A professional survey identifies a potential for joint industrial ventures in agro-based industries; jute, textile, and leather; metal, rubber, and plastic products; transport equipment; electrical and machine tools; mineral-based industries; pharmaceuticals and chemicals; telecommunications; scientific instruments; sports goods, and sericulture. ${ }^{68}$

A SAARC Study Group recommends regional industrial restructuring of the type that fostered South-East Asian industrial integration. ${ }^{69}$ This would imply "relatively more advanced economies of the region. . . (vacating) some stages of production in favor of the others who are laggards in terms of technology and product diversification." new locational patterns of industries and inter-country linkages of supplies and demands. The viability of such a program would depend, above all, on Indo-Pakistan collaboration.

\subsection{Environmental Technological Collaboration}

India and Pakistan share a common ecosystem, rich in biodiversity and genetic resources. The Indo-Pakistan Indus Water Treaty of 1960 has enabled the irrigation of about 24 million acres of land. This Indus spirit can be extended to harness energy and other natural resources for development. One way to increase electricity generation in India and Pakistan is joint utilization of regional hydropower resources and transmission of that electricity through an interconnecting Indian and Pakistani power grid system. Part of the electricity generated by the Indo-Bhutan project could be channeled into India's northern power grid for transfer to Pakistan. Similarly, electricity imported by Pakistan from Tajikistan and Kyrgyzstan might be connected to the Pakistan grid in the Northwest Frontier Province for supply to the subcontinent. Common transmission and distribution networks already operate in North America, Europe, Africa, and the Middle East, and the method can logically work in South Asia. Since India has the world's largest solar energy program, it could transfer this technology for use in Pakistani provinces like Sindh whose terrain and climate are similar to the Indian state of Rajasthan.

\footnotetext{
${ }^{66}$ Gowher Rizvi, op.cit., p. 158.

67 Economic Cooperation In The SAARC Region: Potential, Constraints and Policies, op.cit., p. 161.

68 SAARC Study on Trade, Manufactures and Services (Kathmandu: 1991).

69 Report of the Tripartite Brainstorming Session.

70 Ibid.
} 
India and Pakistan could also meet their deficiency in natural gas by collectively tapping the world's two major natural gas deposits in the Persian Gulf and Central Asia, geographically contiguous to them. For instance, a single gas pipeline (instead of independent gas import options from Iran, Turkmenistan, and Qatar) through Pakistan to India would be cost-effective for both countries. ${ }^{71}$

Bilateral collaboration is also feasible for use of renewable sources of energy and monitoring air and water pollution. ${ }^{72}$ Emissions from automobiles, a major source of air pollution in both countries, could be countered by developing appropriate technology to substitute oil with alternative fuels. India and Pakistan could also undertake joint surveillance on seismic, climatic, and other environmental changes to provide advance warning against droughts, floods, and other natural calamities.

\section{Toward a South Asian Peace}

There are encouraging signs of a growing consciousness for bilateral cooperation at the popular level, demonstrated, for example, by the scenes of solidarity during the crossborder meetings of the Pakistan-India People's Forum For Peace And Democracy. The dialogue launched by Prime Ministers Gujral and Sharif in 1997 has provided impetus for restructuring relations along more cooperative lines. Whichever party assumes power in New Delhi following the parliamentary elections in February 1998, the peace dialogue is unlikely to be undermined.

A sustained dialogue will lead to an incremental reduction of tensions between India and Pakistan, replacing traditional perceptions of hostility and suspicion with mutual understanding and trust. Official policies that encourage people-to-people contact and the free flow of information would foster a favorable climate for the resolution of longstanding differences.

Policy makers in India and Pakistan, as well as influential sectors of the political and economic elite, are also aware of the considerable potential of Indo-Pakistan economic and technological cooperation in areas of "mutually beneficial commonalties" emerged in the wake of economic liberalization. To fully exploit the opportunities presented by this changed political and economic environment, governments in both states must demonstrate their resolve to incrementally revise official policies that have prevented the flow of peoples and ideas across their national borders and that have placed impediments in the path of economic and technological collaboration. The normalization of Indo-Pakistan relations will bring peace to a troubled region and a better life for millions of Indians and Pakistanis.

\footnotetext{
71 The extended line would be particularly helpful for Bangladesh, which has a gas reserve for only 25 years.

${ }^{72}$ Lokesh Misra and Charan D. Wadha, "South Asian Cooperation in the Energy Sector" in Arif A. Waqif ed. Regional Cooperation In Industry and Energy: Prospects for South Asia (Sage, New Delhi, 1991); G.P. Upawansa, "Regional Cooperation in Energy" in ibid., pp. 236-7.

${ }^{73}$ Sanjya Baru, “A Subaltern View of South Asian Economy," Business Standard, April 11, 1997.
} 


\section{About the Authors}

Dr. Samina Ahmed is a specialist on South Asian security and a freelance journalist. She has a master's degree in International Relations and a Ph.D. in Political Science from the Australian National University. Dr. Ahmed has considerable research experience and has published extensively on South Asian security issues. Her publications include the co-edited book, Pakistan and the Bomb: Public Opinion and Nuclear Options, as well as several book chapters and articles in academic journals and the print media.

Dr. Suranjan Das is a University Professor, Department of History, University of Calcutta, and Coordinator, Peace Studies Group, Department of History, University of Calcutta. He received his D. Phil. from the University of Oxford in 1987 for his dissertation on "Communal Riots in Bengal 1905-47." Currently he works on aspects of South Asian regional peace and security. He has a number of publications to his credit and contributes regularly to academic journals and newspapers. 
Movements of People, Ideas, Trade, and Technology:

\section{Distribution}

350 MS 1373 CMC Library, 5341

1 MS 9018 Central Tech Files, 8940-2

2 MS 0899 Technical Library, 4916

2 MS 0619 Review \& Approval Desk, 12690 for DOE/OSTI 